\title{
Determinant Social-Emotional Skills for the Employability in the Graduates of the Continental University
}

\author{
Gustavo Loayza $^{1, *}$, Jorge Sifuentes ${ }^{2}$, Claudia Romero $^{3}$, Meilyn Contreras ${ }^{4}$ \\ ${ }^{1}$ School of Economics, Continental University, Huancayo, Perú \\ ${ }^{2}$ School of Systems and Computer Engineering, Continental University, Huancayo, Perú \\ ${ }^{3}$ Academic Professional School of Management, Continental University, Huancayo, Perú \\ ${ }^{4}$ Academic Professional School of Psychology, Continental University, Huancayo, Perú
}

Received November 17, 2020; Revised June 10, 2021; Accepted June 15, 2021

\section{Cite This Paper in the following Citation Styles}

(a): [1] Gustavo Loayza, Jorge Sifuentes, Claudia Romero, Meilyn Contreras, "Determinant Social-Emotional Skills for the Employability in the Graduates of the Continental University," Universal Journal of Management, Vol. 9, No. 4 pp. 101-112, 2021. DOI: 10.13189/ujm.2021.090401.

(b): Gustavo Loayza, Jorge Sifuentes, Claudia Romero, Meilyn Contreras (2021). Determinant Social-Emotional Skills for the Employability in the Graduates of the Continental University. Universal Journal of Management, 9(4), 101-112. DOI: 10.13189/ujm.2021.090401.

Copyright $\mathrm{C} 2021$ by authors, all rights reserved. Authors agree that this article remains permanently open access under the terms of the Creative Commons Attribution License 4.0 International License

\begin{abstract}
Nowadays, the labor market is more demanding and dynamic, therefore social-emotional skills become a key factor for the employability of university graduates. In that sense, this research had as population of analysis the graduates from 2003 to 2016 of the professional careers of Administration and Systems and Computer of the Continental University. According to the findings, the importance of the competencies of self-awareness, self-management, awareness of others, social skills and responsible decision-making is evident, skills that are part of the methodology of Socio-Emotional Learning (SEL). The qualitative method was used, with a non-experimental design of the descriptive transversal type, applying the Delphi survey and prospective method as a data collection technique. As a result of the research, it is observed that the most valued and important competence for employers is Responsible Decision-Making for both careers, with $41 \%$ in Administration and $47 \%$ in Systems and Computer Engineering. In the case of the Systems and Computer Engineering career, it coincides with the ability that graduates of this degree have developed during their university career, while graduates of the Administration degree have more developed Social Skills by $39.3 \%$.
\end{abstract}

Keywords Social-Emotional Skills, Employability, Graduates, Labor Market

\section{Introduction}

Advances in information technology, the search for productivity and business competitiveness directly impact the Peruvian labor market. This is evidenced by the recurring claims of employers: the shortage of talent among employees. According to (ManpowerGroup, 2018, p. 2) [13], the talent shortage is global, thus employers must adjust their hiring strategies to one that combines: skills, processes and technologies. In Peru, $43 \%$ of employers report that workers do not have hard skills and human strengths (soft skills). Even in companies with more than 250 employees, this percentage grows to $54 \%$.

Research has shown that social-emotional skills are more important in the labor market than even hard skills. In efforts to investigate the dynamics of work and the creation of opportunities, the (African Development Bank Group et al., 2018, p. 23) [1] states that in the face of rapid advances in technology and machinery, it is reasonable to maintain an advantage over them, humans will have to continue learning to solve new and increasingly complex problems through social-emotional skills and creativity; it states that basic educational skills should be oriented to 
helping people learn to learn and improve these skills. In the face of this, universities are committed to improving educational processes so that they allow graduates to have the skills that the labor market needs. In this regard, this is where the question arises: on what does the employability of a university graduate depend? As mentioned by (Layer, 2004, p. 16) [11], the concern and unease in correlation to university education and the labor market are greater, so the purpose of this research is to highlight those skills that are valued in organizations. Likewise, this finding will allow universities to reinforce and/or improve their curriculum summaries in order to complement hard skills with social-emotional skills.

\section{Social - Emotional Competencies}

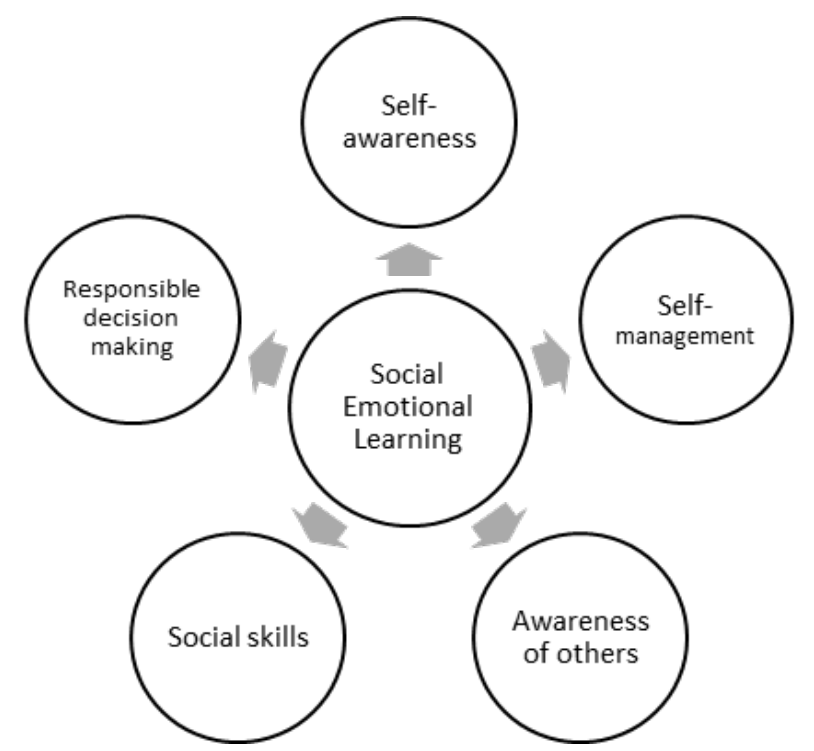

Source: Taken from CASEL, SEL's systemic framework

Figure 1. Social-emotional competencies

According to the Collaborative for Academic, Social, and Emotional Learning, social-emotional competencies are the process by which we acquire and apply the knowledge, attitudes, and skills needed to understand and manage emotions, determine and achieve goals, feel and show empathy, establish and maintain healthy, positive relationships, and make responsible decisions, in other words, the ability to perform well in complex and authentic contexts (CASEL, 2010 a p. 3) [5]. According to (Extremera \& Pena, 2015, p. 172) [7], social-emotional competencies should be stimulated and cultivated, since they are basic skills to facilitate employability; since this set of skills determines the way of working, the attitude towards employment and life, or the way of relating to others, such as the harmonious way of working in a team or the resistance to adversity. Therefore, social-emotional skills not only help to find employment quickly, but also facilitate more options for promotion and advancement within the organization, as well as staying in the job in an increasingly changing and dynamic working world. For this research, the methodology used is the five competencies proposed by (CASEL, 2010b, p. 4) [5], a leading organization in research on design and implementation of social and emotional learning programs, which was adapted by (SELChile, 2019) [17] with the aim of improving the positive impact on the quality of learning in their students, educators and families.

Self-awareness: According to (Jagers et al., 2019a, p. 167) [10], self-awareness allows us to self-examine our thoughts, values and emotions, and articulate them with our actions and behaviors. It is having the potential to recognize our own weaknesses and strengths, supported by a growth mentality, optimism and confidence. Within this competence are the following skills: recognition of emotions, recognition of interests, values and abilities, self-evaluation and self-knowledge.

Self-management: This competence recognizes our own thoughts, emotions and behaviors satisfactorily in different situations. In addition, it allows us to manage stress, develop self-motivation and control impulses; self-motivation refers to the ability to set and work on goals, whether personal or academic. This competence is composed of: self-control, impulse and behavior management, handling and proper expression of emotions and self-motivation, achievement of personal goals.

Awareness of others: Ability to empathize with others and have perspective on them. It is recognizing and understanding the social and ethical norms of behavior, recognizing and valuing the support and resources that come from the community, school and family. The skills that are part of this competence are: empathy, perspective taking.

Social skills: Competence that allows to maintain and establish in the long term positive, pleasant and satisfactory relationships based on participation. It is expressing oneself clearly, cooperating with others, knowing how to listen, opposing social pressure, solving problems in a constructive way, seeking and providing support when necessary. The skills found in this competence are: establishing and maintaining healthy and rewarding relationships, teamwork, cooperation, dialogue and participation, assertive communication and peaceful conflict resolution.

Responsible decision-making: Supported by ethical standards, responsible decision-making is the willingness to make beneficial decisions about social interactions and self-behavior, where social norms are considered. This competence assesses the well-being of others and the consequences of one's actions (Jagers et al., 2019b, p. 167) [10]. Moral reasoning and responsible decision-making are part of this competency.

\section{Employability and Graduates}

According to the International Labour Organization, 
employability is the ability of a person to find and keep a job, to progress in work and to adapt to change throughout professional life; therefore, employability is congruent with the development and profiling of skills that are valued and appreciated in the world of work. In summary, it is considered the presence of a chain of skills that optimize the possibilities of people who have them to find a job and keep it over time (García et al., 2008a , p. 5) [8]. (Real Academia Española, 2019) [16] defines employability as the set of skills and attitudes that allow a person to get a job and keep it, so with such a definition we can deduce how important the socio-emotional factor is. According to (Campos, 2003, p. 8) [4], employability skills are the attributes of people who do not attend to their technical competencies, which causes serious opinions among employers because of the lack of non-technical skills in their staff. At present, employability is a key factor in the new educational model and, indeed, it is strengthened by the development and acquisition of professional competencies, such as technical and non-technical skills; (García et al., 2008b, p. 8) [8] mentions that the concept of employability should not be confused with that of labor market insertion, since employability develops a long-term vision, while labor market insertion develops a short-term one. However, there are two main concerns that attract the curiosity of researchers, the main one being related to the substantial or key competencies that mediate and influence the victory of graduates, and the second refers to how and when those competencies have been acquired or developed. According to (Cotton, 1993, p. 3) [6], who observed in different surveys that employers are generally satisfied with the technical skills of university students, but conversely, they are not completely satisfied with the employability and non-technical skills; that is, it can be stated that employers estimate the basic employability skills above the specific skills. Other authors, such as (Stasz, 1998, p. 188) [19], mention that it is more important to enhance generic skills, since they argue that employers and workers show a need for both generic skills and problem-solving, communication, and teamwork skills. Given this reality, higher education institutions have an important role in the development of professional skills, such as educating their students so that they can efficiently develop a professional activity that is sustainable over time.

\section{Method}

\subsection{Research Model}

The method applied to this research is the qualitative one, since according to (Bernal, 2010) [3] this method is oriented to describe the social phenomenon from determining features, as perceived by the very elements that are within the situation studied. The research design is non-experimental, of the transectional or cross-sectional descriptive type, since data on existing skills in graduates of the Continental University was collected.

\subsection{Study Group}

The population for this research, was composed by graduates of the professional careers of Administration and Systems and Computer Engineering of the Continental University, who have more than three years of graduation, since it is considered the period from 2003 to 2016. This choice was made based on the model of the (Sistema Nacional de Evaluación Acreditación y Certificación de la Calidad Educativa, 2017) [18] SINEACE (see Appendix 7), a specialized technical organization that states that the achievement of competencies in graduates is visualized or observable after three years of graduation.

\subsection{Data Collection Techniques and Instruments}

For the purposes of this research, data were collected from fifty graduates of the professional careers of Administration and Systems and Computer Engineering at the Continental University under the non-probabilistic method and convenience sampling, likewise data were obtained from fifty employers of graduates of the careers under study. The survey was applied as a technique for collecting data on the graduates and their employers, in which the graduate surveyed had to mark the degree to which he or she developed and applied social-emotional skills, from a very low degree to a very high degree, and for the employers to mark the degree of importance and value of the skills at present and for the future. Additionally, in this group the prospective technique of the Delphi method (see Appendix 5) was applied, since it seeks to obtain reliable and objective opinions.

\section{Results}

The results were obtained thanks to direct coordination with the Continental University and contact with graduates of the Administration and Systems and Computer Engineering careers and their employers. The surveys on social-emotional skills were taken in June and July 2019, in which the Delphi method was put into practice with the heads of the graduates contacted.

The Appendix 1 presents the results obtained from the application of the survey to graduates of the professional careers of Administration and Systems and Computer Engineering. The expressed percentages correspond to the analysis of the score 4 and 5 ("high" and "very high" respectively (see Appendix 1), this with the purpose of obtaining a unique comparison between the acquired or developed abilities in the Higher Education Institute (HEI) 
and the abilities that are applied in the institutions where the graduates of the mentioned careers work. Based on these results, we can affirm that the skills that were most developed by the graduates belong to the dimensions of Social Skills (Administration: 39.3\%, Systems Engineer 34\%) and Responsible Decision-Making (Administration: $37.5 \%$, Systems Engineer 35\%). And the ones that were less developed are: Self-awareness and Self-management, with an average between $28 \%$ and $32.8 \%$.

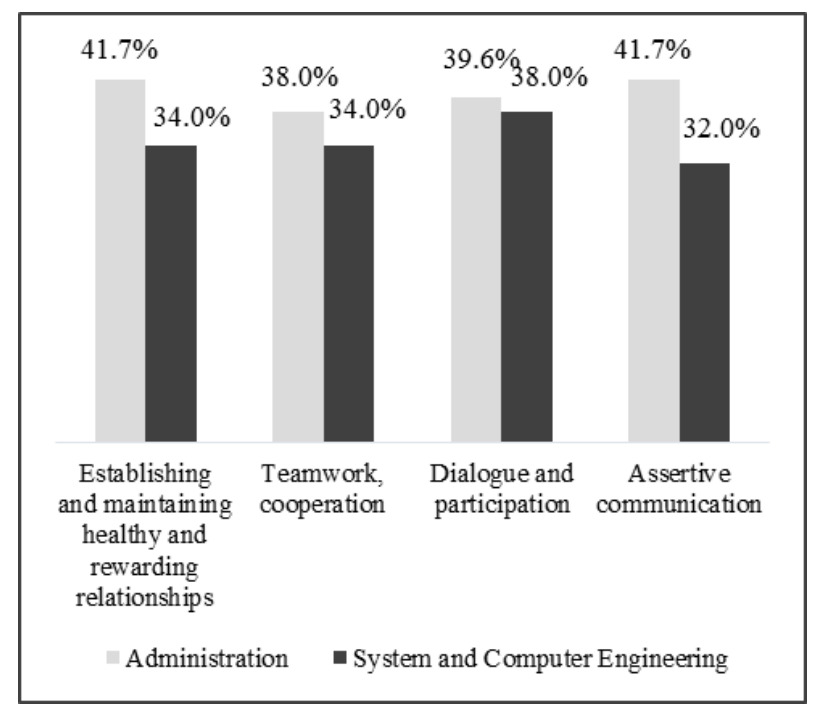

Figure 2. Comparison of the Social Skills developed by the graduates of the HEI

Figure 2 shows that it is the skills belonging to the competition: Social Skills that have the highest score, that is, those that were most developed in the HEI. However, we can also see that it is the Administration career that shows better percentages; the Social Skills competence has an average of $39.3 \%$ (Appendix 1), while the Systems and Computer Engineering career has 34\%. This reflects the graduation profile of each professional career and the development of subjects and activities in each specialty.

As indicated in (Universidad Continental, 2006, p. 3) [21] the graduates of the career of Systems and Computer Engineering are capable of leading software engineering projects of different size and complexity, having a computer as their main and fundamental tool. While in the career of Administration, the graduation profile is oriented to the identification of needs for the proposal of products and services, which promotes interaction with specific groups and identification of opportunities (Universidad Continental, 2006, p. 3) [20].

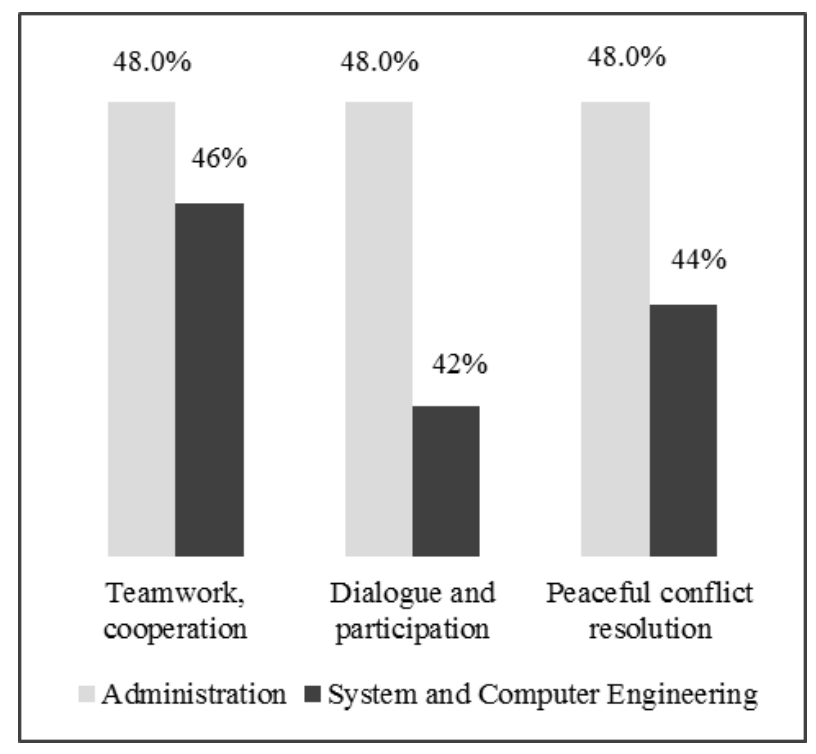

Figure 3. Comparison of Social Skills applied by graduates in the organization

Evidently, there is a greater application of the skills in the labor field, so Figure 2 and 3 show the percentage increase of each skill belonging to the Social Skills competence. Learning opportunities are still present in the world of work, since the labor market constantly informs about which investments in skills could be the most profitable (salary). This is because of the activities related to work, as mentioned by the (Banco de Desarrollo de América Latina, 2016, p. 38) [2], having more skills implies better quality work development. In addition, the graduates of both careers who were surveyed said that today they apply much more of the skills they developed at their university, of which the most representative are teamwork, cooperation, peaceful conflict resolution, dialogue, and participation. 


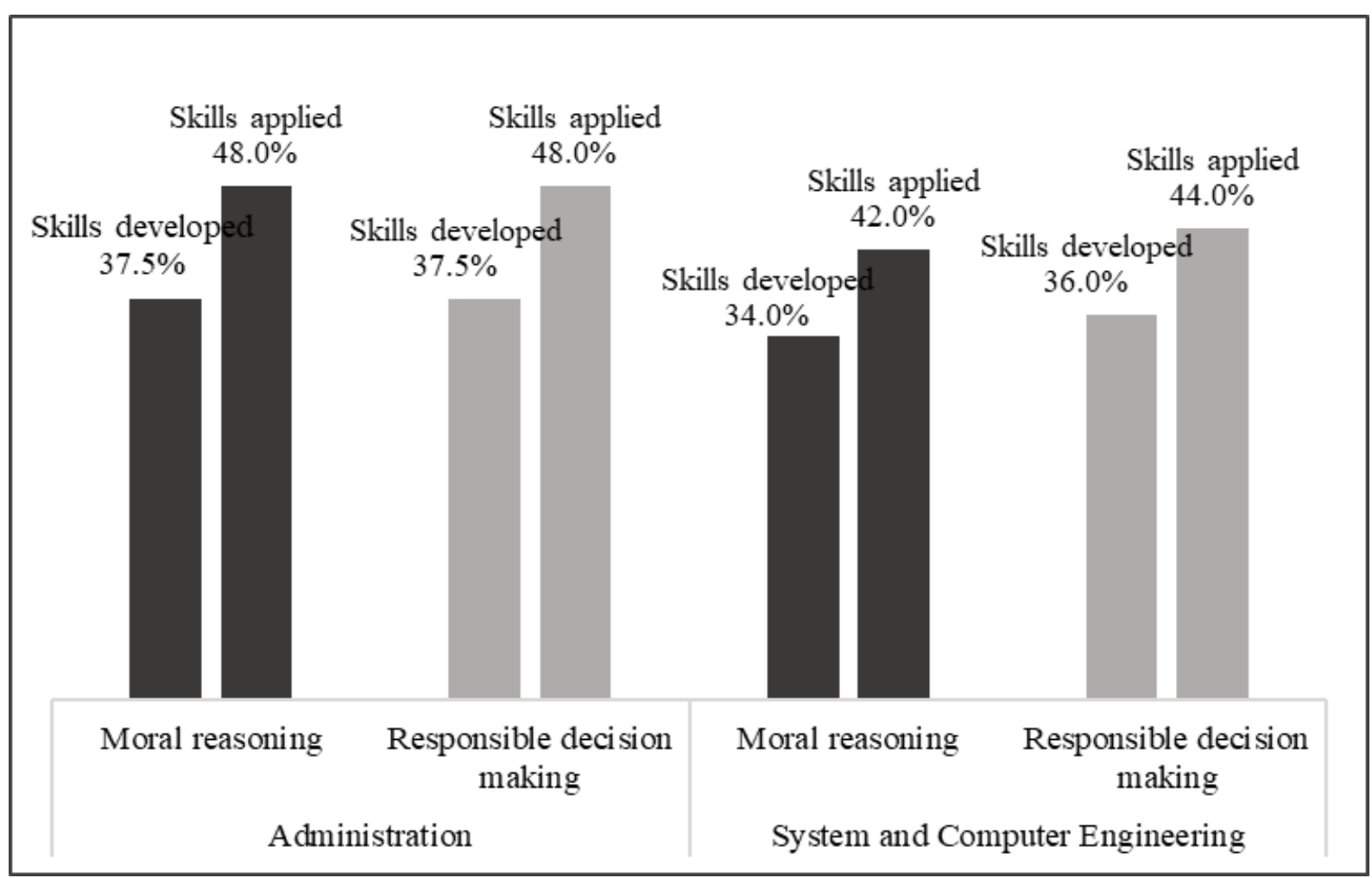

Figure 4. Comparison between skills acquired in the HEI vs. those applied in the organization, by professional career. Competence: Responsible Decision-Making.

Figure 4 shows the competence Responsible Decision-Making, in it we have two skills, being these: moral reasoning and responsible decision-making itself. We can see the importance of the application of the skills in the development of employment activities, with the percentage increase on average being $10.5 \%$ considered by the graduates surveyed. For the graduates of both careers is very high and important to have the ability to make responsible decisions, because in their day to day competitive environments that require the evaluation of scenarios with minimal potential for error and avoiding putting the organization at risk (Villanueva Flores, 2015) [22].

In Appendix 2, the results of the surveys developed by the employers of the Administration and Systems and Computer Engineering careers are shown. The percentages are obtained from the average of the highest values within the Likert scale, with the score 4 and 5 (important, very important); since it could be observed that most of the surveyed employers marked based on these two scores.

According to this, it can be seen that at present employers consider that the Responsible Decision-Making competence (Adm.: 41\%, Sys. Engr.: 47\%) is of greater importance and application, because in the hands of the professionals of the careers of study, the horizon of the organization is found. The same happens with the competence Awareness of others (Adm.: 40\%, Sys. Engr.: 46\%) and finally, Social Skills competence (Adm.: 38\%, Sys. Engr.: 46\%). In addition, the employers interviewed consider that in the future social-emotional skills will become more important in the labor market, so that they intervene in the selection processes as part of the requirements for obtaining a job, as well as for staying in it. Therefore, they will look for an efficient development of the applicant throughout his professional growth and development. 


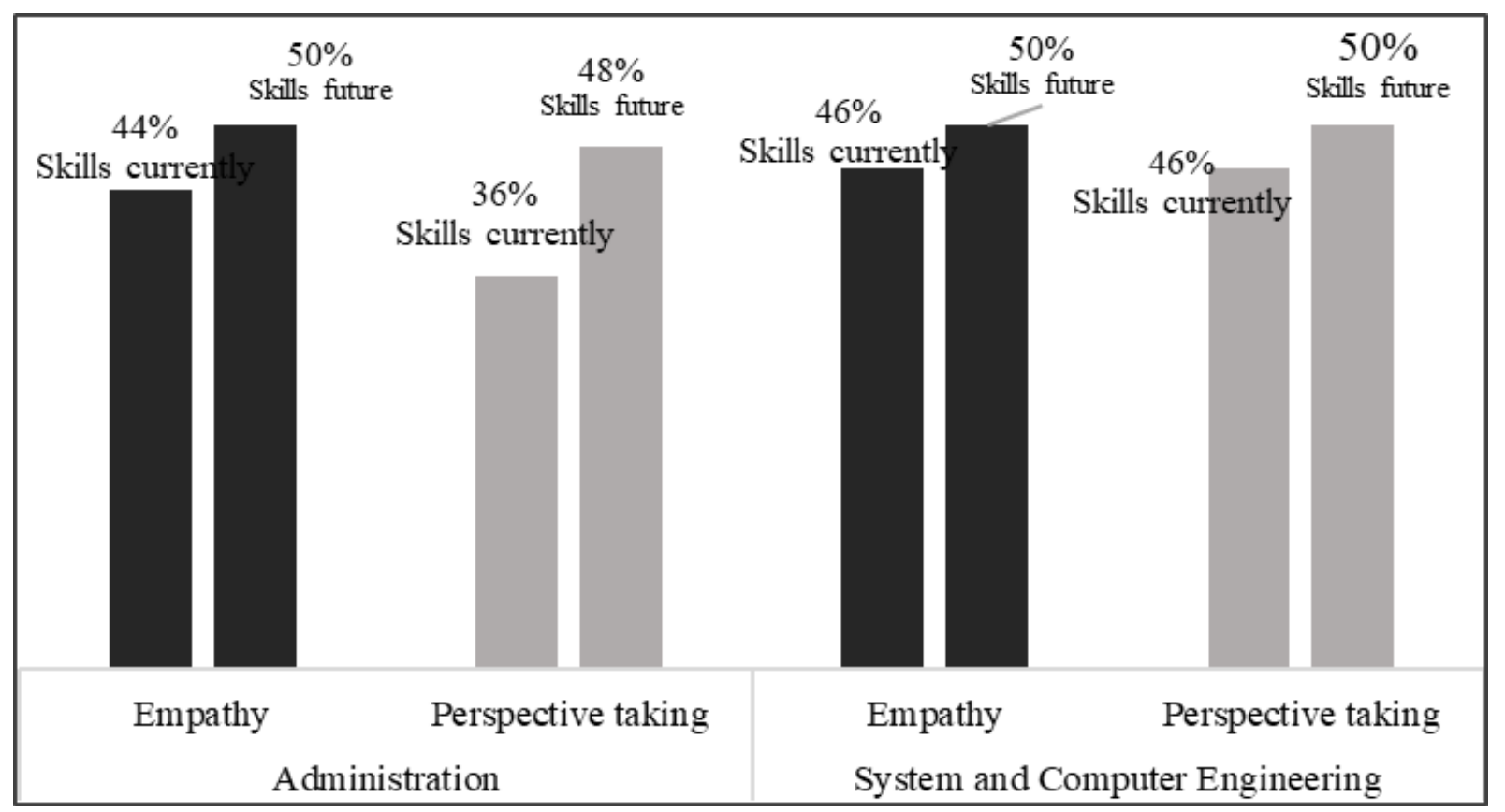

Figure 5. Comparison of skills valued in the present vs. skills that will be valued in the future. Competence: Awareness of others.

Figure 5 shows the comparison of the skills valued in the present and those that will be valued in the future in the organization. According to the experts, organizations tend to value empathy and the taking of perspective for the achievement of objectives set within each area, as well as the interrelationship with their peers. However, these skills will be more valued in the future, since it is expected that within the work the collaborators can empathize and have vision of achievements, recognizing and understanding the social norms within an organization.

The figure in Appendix 3 shows that, although the ability of handling and suitable expression of emotions, at the present time is valued in average a $30 \%$ by the employers of the Administration career, this ability must be developed and given more emphasis, since in the future it is going to be valued that each collaborator can handle his emotions in a suitable way to obtain an optimal labor atmosphere, knowing how to deal with opposite opinions of his pairs, as well as to solve problems within and outside the organization. A similar case happens in Systems and Computer Engineering, where the ability to self-motivate, to achieve personal goals, is valued at $32 \%$, low in comparison with the other skills within this competence. According to experts, this is because very few organizations take into account the personal and professional aspirations of their employees, largely because the focus is productive and commercial, so they leave aside human resource management. However, it should be noted that, in the future, each employee will be considered to develop the capacity to be self-motivated, so that they can face complex day-to-day situations in a reflective manner, since considering the challenges and difficulties involved in work from a positive perspective is motivating, but doing so from a negative point of view causes us to become unmotivated (Maella, 2016: 44) [12].

In the table of Appendix 4, it can be observed that the ability considered with smaller value at the present time by the employers of the Administration career is the pacific resolution of conflict with a $32 \%$ as in the Systems and Computer Engineering career with $44 \%$; nevertheless, the labor market is in constant change since now it is required professionals of knowledge that carry ample functions and that can solve conflicts efficiently, in such a way that the employers will value the initiative capacity of the collaborator (proactivity), the adaptation to the changes and the integration to the organization (Pérez de los Cobos, 2010: 448) [15]. Also, currently the most valued skill by employers in the Administration career is to establish and maintain healthy and rewarding relationships, while in the Systems and Computer Engineering career, the ability to work in teams and cooperation. The latter is considered fundamental for the proper functioning and growth of the institution, since it brings advantages. Among them is the increase of the work climate in the area for being happy and showing energy to the activities; this satisfaction brings with it productivity and performance (Gómez, 2015) [9].

With regard to figure 6 , it can be seen that the skills corresponding to the Responsible Decision-Making competence, in the future will be valued by the companies to ensure the continuous growth of the organization. As for the Administration career, employers consider that the ability of moral reasoning currently has a greater presence in organizations (42\%); meanwhile in the Systems and Computer Engineering career, the ability of responsible decision-making $(48 \%)$, is fundamental in the present and will continue to be so in the future. 
People who are faced with making decisions in the day-to-day running of the organization may have some kind of moral contradiction, as their values may or may not be aligned with the philosophy of the institution. Therefore, the experts believe that professionals must develop the ability to make reasoned and informed decisions in which they analyze the behavior and consequences of their actions (Montuschi, 2004, p. 15) [14].

\section{Conclusions}

The research allowed the identification of the skills that Continental University has developed in the graduates of the Administration and Systems and Computer Engineering careers throughout their university studies, as well as the skills that are in demand by employers today (see Appendix 6) and those that will be valued in the future.

Within the research, it can be stated that the least developed skill in the university for both careers was Self-Management, while the most developed skill in the Administration career was Social Skills and in Systems and Computer Engineering, the Responsible Decision-Making skill. In that sense, this development of skills within their house of studies has allowed that these can be applied in the organization where they work, due to the demands of their work environment, in order that these have become professional competences.

On the other hand, the most valued skill in the present by the experts of both professional careers, is the Responsible Decision-Making; however, according to the experience and continuous learning of the employers, they consider that all the competences like Self-Awareness, Self-Management, Awareness of others, Social Skills and Responsible Decision-Making will be valued and important in the future within the profile of each professional for the integration and development of the collaborators in diverse work areas.

Finally, with the results of this research, it is affirmed that the social-emotional skills will be determinant in its totality for the employability in the future, since at present it is being required more and more in the labor profiles of the organizations. In that sense, with these results and conclusions, the centers of university studies will be able to include content referring to the social-emotional abilities in subjects and/or workshops of employability, in such a way that the students who are about to graduate will have these abilities and will improve their competitiveness.

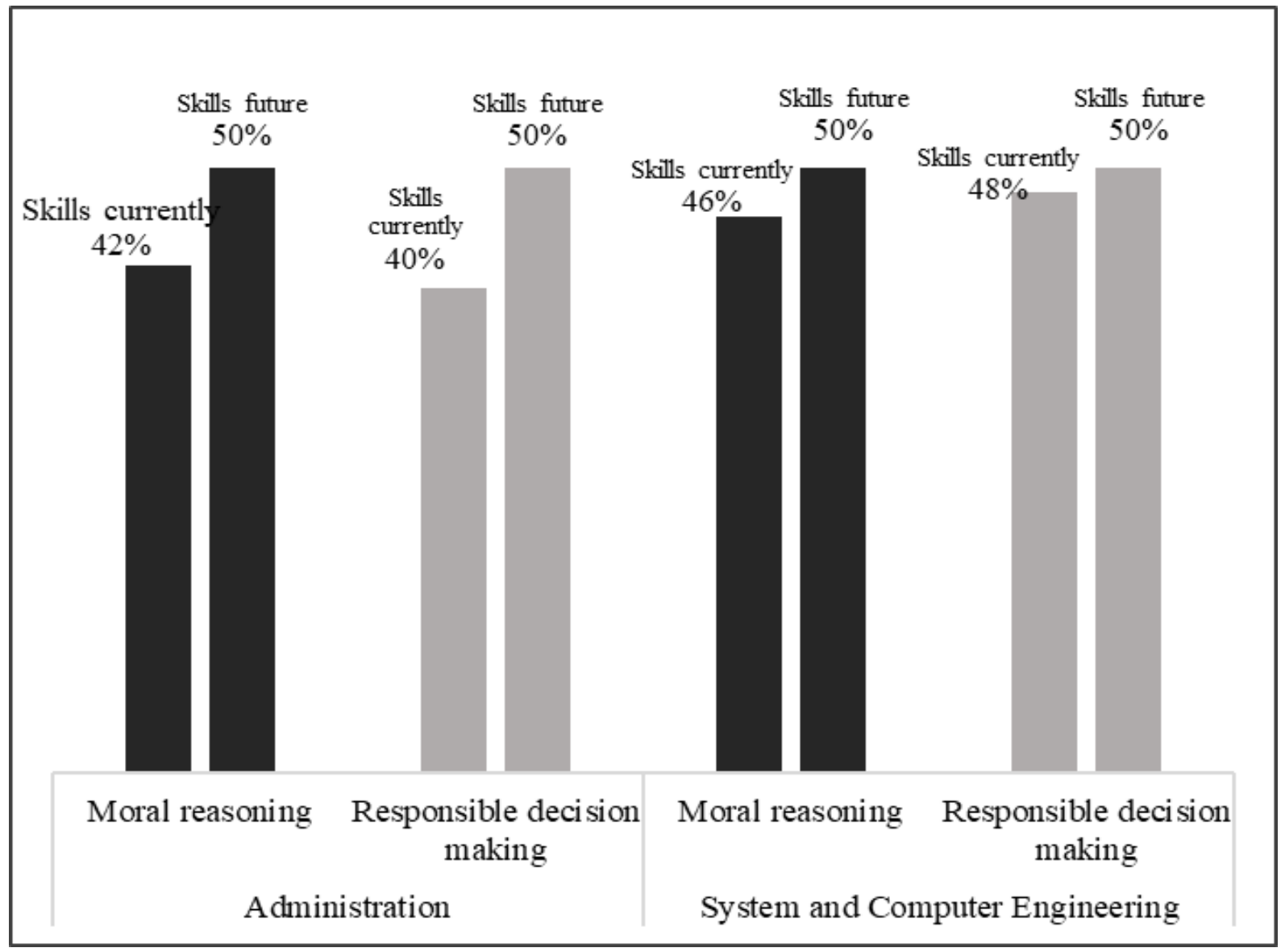

Figure 6. Comparison of skills valued in the present vs. skills that will be valued in the future. Competence: Responsible decision-making. 


\section{Appendix 1 - General Results of the Social-Emotional Skills Developed in the HEI and Applied in the Organization}

\begin{tabular}{|c|c|c|c|c|}
\hline \multirow[b]{2}{*}{$\begin{array}{l}\text { Social-emotional skills developed in the center of } \\
\text { higher studies and applied in the organization. }\end{array}$} & \multicolumn{2}{|c|}{ Skills developed at the university } & \multicolumn{2}{|c|}{ Skills applied in the organization } \\
\hline & Administration & $\begin{array}{l}\text { Systems and } \\
\text { Computer } \\
\text { Engineering } \\
\end{array}$ & Administration & $\begin{array}{c}\text { Systems and } \\
\text { Computer } \\
\text { Engineering } \\
\end{array}$ \\
\hline Recognize of emotions & $22.9 \%$ & $22 \%$ & $42 \%$ & $38 \%$ \\
\hline Recognize of interests, values and abilities & $39.6 \%$ & $34 \%$ & $42 \%$ & $38 \%$ \\
\hline Self-evaluation & $35.4 \%$ & $34 \%$ & $42 \%$ & $42 \%$ \\
\hline Self-knowledge & $33.3 \%$ & $30 \%$ & $46 \%$ & $42 \%$ \\
\hline SELF-AWARENESS & $32.8 \%$ & $30 \%$ & $43 \%$ & $40 \%$ \\
\hline Self-control, impulse and behavior management & $22.9 \%$ & $20 \%$ & $46 \%$ & $40 \%$ \\
\hline Handling and proper expression of emotions & $31.3 \%$ & $28 \%$ & $48 \%$ & $38 \%$ \\
\hline Self-motivation, achievement of personal goals & $37.5 \%$ & $36 \%$ & $46 \%$ & $44 \%$ \\
\hline SELF-MANAGEMENT & $30.6 \%$ & $28 \%$ & $46.7 \%$ & $41 \%$ \\
\hline Empathy & $39.6 \%$ & $32 \%$ & $46 \%$ & $40 \%$ \\
\hline Perspective taking & $33.3 \%$ & $26 \%$ & $46 \%$ & $40 \%$ \\
\hline AWARENESS OF OTHERS & $36.5 \%$ & $29 \%$ & $46 \%$ & $40 \%$ \\
\hline $\begin{array}{l}\text { Establishing and maintaining healthy and rewarding } \\
\text { relationships }\end{array}$ & $41.7 \%$ & $34 \%$ & $46 \%$ & $38 \%$ \\
\hline Teamwork, cooperation & $38 \%$ & $34 \%$ & $48 \%$ & $46 \%$ \\
\hline Dialogue and participation & $39.6 \%$ & $38 \%$ & $48 \%$ & $42 \%$ \\
\hline Assertive communication & $41.7 \%$ & $32 \%$ & $46 \%$ & $40 \%$ \\
\hline Peaceful conflict resolution & $35.4 \%$ & $32 \%$ & $48 \%$ & $44 \%$ \\
\hline SOCIAL SKILLS & $39.3 \%$ & $34 \%$ & $47.2 \%$ & $42 \%$ \\
\hline Moral reasoning & $37.5 \%$ & $34 \%$ & $48 \%$ & $42 \%$ \\
\hline Responsible decision-making & $37.5 \%$ & $36 \%$ & $48 \%$ & $44 \%$ \\
\hline RESPONSIBLE DECISION-MAKING & $37.5 \%$ & $35 \%$ & $48 \%$ & $43 \%$ \\
\hline
\end{tabular}

Source: Elaborated by the authors 


\section{Appendix 2 - Overall Social-Emotional Skills Results as Assessed by the Employer in the Present and Future}

\begin{tabular}{|c|c|c|c|c|}
\hline \multirow[b]{2}{*}{$\begin{array}{l}\text { Social-emotional skills valued in the present and future } \\
\text { by employer }\end{array}$} & \multicolumn{2}{|c|}{ Skills currently valued } & \multicolumn{2}{|c|}{ Skills valued in the future } \\
\hline & Administration & $\begin{array}{l}\text { Systems and } \\
\text { Computer } \\
\text { Engineering }\end{array}$ & Administration & $\begin{array}{c}\text { Systems and } \\
\text { Computer } \\
\text { Engineering }\end{array}$ \\
\hline Recognize of emotions & $36 \%$ & $30 \%$ & $50 \%$ & $50 \%$ \\
\hline Recognize of interests, values and abilities & $38 \%$ & $34 \%$ & $50 \%$ & $50 \%$ \\
\hline Self-evaluation & $38 \%$ & $26 \%$ & $46 \%$ & $50 \%$ \\
\hline Self-knowledge & $30 \%$ & $42 \%$ & $46 \%$ & $50 \%$ \\
\hline SELF-AWARENESS & $36 \%$ & $33 \%$ & $48 \%$ & $50 \%$ \\
\hline Self-control, impulse and behavior management & $32 \%$ & $36 \%$ & $50 \%$ & $50 \%$ \\
\hline Handling and proper expression of emotions & $30 \%$ & $40 \%$ & $50 \%$ & $50 \%$ \\
\hline Self-motivation, achievement of personal goals & $46 \%$ & $32 \%$ & $50 \%$ & $50 \%$ \\
\hline SELF-MANAGEMENT & $36 \%$ & $36 \%$ & $50 \%$ & $50 \%$ \\
\hline Empathy & $44 \%$ & $46 \%$ & $50 \%$ & $50 \%$ \\
\hline Perspective taking & $36 \%$ & $46 \%$ & $48 \%$ & $50 \%$ \\
\hline AWARENESS OF OTHERS & $40 \%$ & $46 \%$ & $49 \%$ & $50 \%$ \\
\hline $\begin{array}{c}\text { Establishing and maintaining healthy and rewarding } \\
\text { relationships }\end{array}$ & $46 \%$ & $46 \%$ & $50 \%$ & $50 \%$ \\
\hline Teamwork, cooperation & $36 \%$ & $48 \%$ & $50 \%$ & $50 \%$ \\
\hline Dialogue and participation & $34 \%$ & $44 \%$ & $50 \%$ & $50 \%$ \\
\hline Assertive communication & $42 \%$ & $46 \%$ & $50 \%$ & $50 \%$ \\
\hline Peaceful conflict resolution & $32 \%$ & $44 \%$ & $50 \%$ & $50 \%$ \\
\hline SOCIAL SKILLS & $38 \%$ & $46 \%$ & $50 \%$ & $50 \%$ \\
\hline Moral reasoning & $42 \%$ & $46 \%$ & $50 \%$ & $50 \%$ \\
\hline Responsible decision-making & $40 \%$ & $48 \%$ & $50 \%$ & $50 \%$ \\
\hline RESPONSIBLE DECISION-MAKING & $41 \%$ & $47 \%$ & $50 \%$ & $50 \%$ \\
\hline
\end{tabular}

Source: Elaborated by the authors

\section{Appendix 3 - Comparison of Skills Assessed in the Present vs. Skills that Will be Assessed in the Future Competency: Self-management}

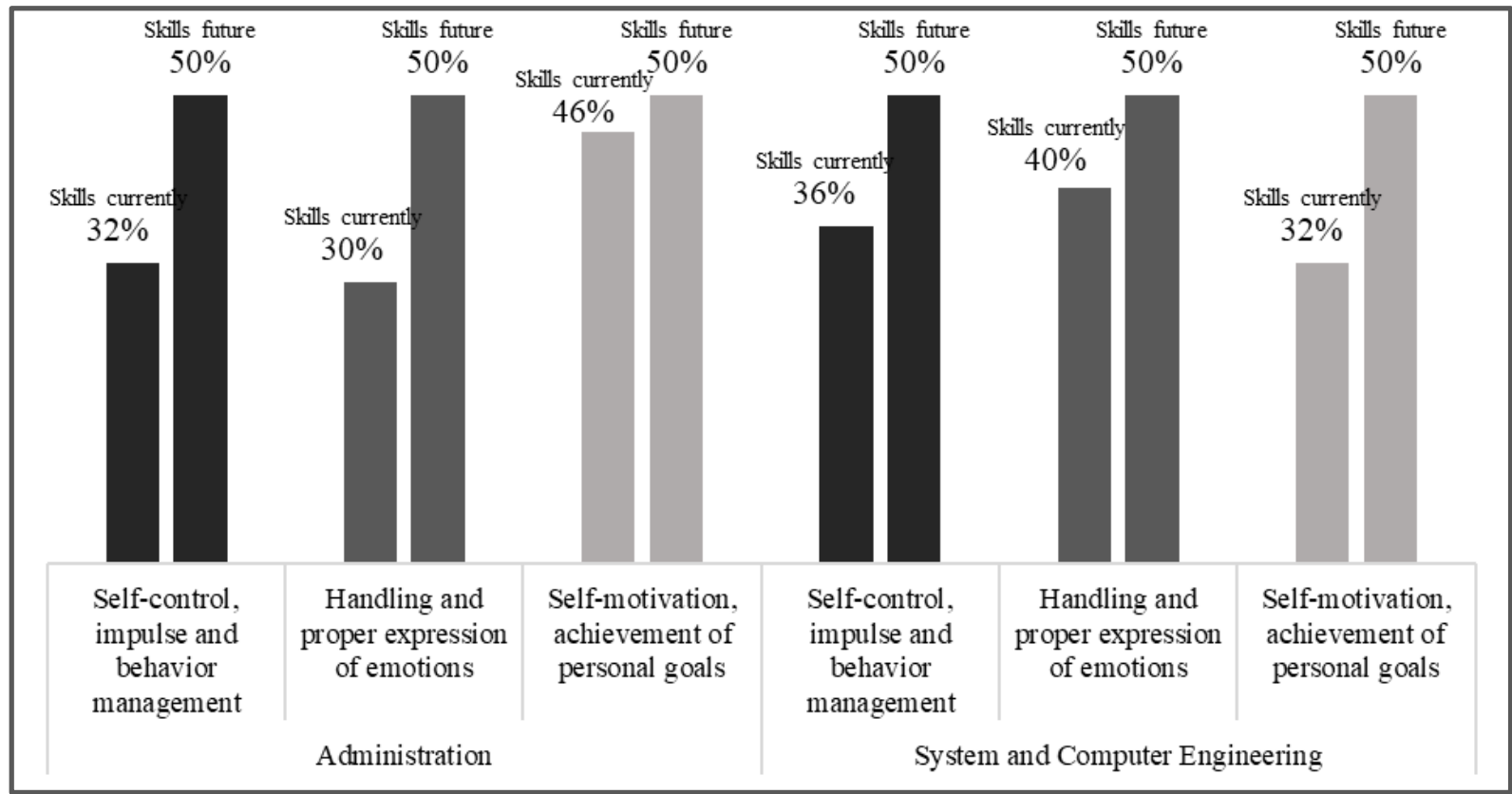




\section{Appendix 4 - Comparison of Skills Assessed in the Present vs. Skills that Will be Assessed in the Future Competency: Social Skills}

\begin{tabular}{|c|c|c|c|c|}
\hline \multirow{2}{*}{ Social Skills } & \multicolumn{2}{|c|}{ Administration } & \multicolumn{2}{c|}{ Systemsand Computer Engineering } \\
\cline { 2 - 5 } & $\begin{array}{c}\text { Skills currently } \\
\text { valued }\end{array}$ & $\begin{array}{c}\text { Skills valued } \\
\text { in the future }\end{array}$ & $\begin{array}{c}\text { Skills currently } \\
\text { valued }\end{array}$ & $\begin{array}{c}\text { Skills valued in } \\
\text { the future }\end{array}$ \\
\hline $\begin{array}{c}\text { Establishing and maintaining healthy and rewarding } \\
\text { relationships }\end{array}$ & $46 \%$ & $50 \%$ & $46 \%$ & $50 \%$ \\
\hline Teamwork, cooperation & $36 \%$ & $50 \%$ & $48 \%$ & $50 \%$ \\
\hline Dialogue and participation & $34 \%$ & $50 \%$ & $44 \%$ & $50 \%$ \\
\hline Assertive communication & $42 \%$ & $50 \%$ & $46 \%$ & $50 \%$ \\
\hline Peaceful conflict resolution & $32 \%$ & $50 \%$ & $44 \%$ & $50 \%$ \\
\hline
\end{tabular}

\section{Appendix 5 - Description of the Delphi Method Applied}

\begin{tabular}{|c|l|}
\hline Steps & \multicolumn{1}{|c|}{ Description } \\
\hline Definition of the topic & $\begin{array}{l}\text { The authors selected the topic according to the problems presented by recruitment } \\
\text { recruiters. }\end{array}$ \\
\hline Elaboration of the instrument & The questions in the questionnaire were elaborated. \\
\hline Application of the questionnaire & $\begin{array}{l}\text { Graduates from 2003 to } 2016 \text { of the professional careers of Systems and Computer } \\
\text { Engineering and Administration were surveyed. Additionally, employers were contacted; } \\
\text { this public participated as experts for the Delphi Method. }\end{array}$ \\
\hline Tabulation of results & $\begin{array}{l}\text { The results obtained from the graduates and employers of the mentioned careers were } \\
\text { processed. }\end{array}$ \\
\hline Expert participation & $\begin{array}{l}\text { The authors arranged for the employers of each career path to be the experts within the } \\
\text { Delphi method. }\end{array}$ \\
\hline Role of experts & $\begin{array}{l}\text { It was explained to the experts what their contribution and participation in this research } \\
\text { would be, being this in the interpretation of the results obtained from the employers. }\end{array}$ \\
\hline $\begin{array}{c}\text { First round } \\
\text { Discussion of results }\end{array}$ & $\begin{array}{l}\text { Results obtained from the employers were discussed while maintaining anonymity among } \\
\text { them. }\end{array}$ \\
\hline Analysis and feedback of the first round & The experts commented on the results and had some contrary ideas among themselves. \\
\hline $\begin{array}{c}\text { Second round } \\
\text { Discussion and conclusion of results }\end{array}$ & $\begin{array}{l}\text { The results were again shared with the experts for their comments, seeking to reach a } \\
\text { consensus and consolidate the skills identified. }\end{array}$ \\
\hline Conclusion of results & The results were concretized, obtaining reliable and objective opinions. \\
\hline
\end{tabular}

\section{Appendix 6 - Ranking of Skills Demanded by Employers}

\begin{tabular}{|c|c|}
\hline $\mathbf{N}^{\circ}$ & Social-emotional skills \\
\hline 1 & Establishing and maintaining healthy and rewarding relationships \\
\hline 2 & Empathy \\
\hline 3 & Assertive communication \\
\hline 4 & Moral reasoning \\
\hline 5 & Responsible decision-making \\
\hline 6 & Teamwork, cooperation \\
\hline 7 & Perspective taking \\
\hline 8 & Self-motivation, achievement of personal goals \\
\hline 9 & Dialogue and participation \\
\hline 10 & Peaceful conflict resolution \\
\hline 11 & Recognize of interests, values and abilities \\
\hline 12 & Self-knowledge \\
\hline 13 & Handling and proper expression of emotions \\
\hline 14 & Self-control, impulse and behavior management \\
\hline 15 & Recognize of emotions \\
\hline 16 & Self-evaluation \\
\hline
\end{tabular}




\section{Appendix 7 - The SINEACE Model}

The SINEACE (https://www.gob.pe/sineace) is the National System of Evaluation, Accreditation and Certification of Educational Quality in Peru. It is an institution whose function is the evaluation, accreditation and certification of competencies in the different Peruvian university professional careers. The evaluation of competencies is referred to as "Measurement of Educational Objectives", which is performed to university graduates with more than 3 years of graduation or completion their university studies.

According to SINEACE, the process that will be applied is:

- The syllabus identifies the periodicity of the review of the graduate profile. The review shall be carried out in a maximum period of 3 years.

- This review will be conducted by the directors of the syllabus, with the participation of stakeholders and other actors that the program of studies considers appropriate.

- The review of the profile considers: professional performance, scientific and technological advances, new demands of the academic community and the environment, among others. If applicable, this review ends with the definition of the new graduate profile.

More information: https://www.sineace.gob.pe/wp-cont ent/uploads/2014/08/Anexo-1-nuevo-modelo-programasResolucion-175.pdf

\section{REFERENCES}

[1] African Development Bank Group, Asian Development Bank, Banco Interamericano de Desarrollo, European Bank for Reconstruction and Development (2018). El futuro del trabajo: perspectivas regionales. Washington, DC, BID.

[2] Banco de Desarrollo de América Latina (2016), Más habilidades para el trabajo y la vida: los aportes de la familia, la escuela, el entorno y el mundo laboral, Bogotá, Corporación Andina de Fomento.

[3] Bernal, C. (2010). Metodología de la Investigación. Bogotá, Pearson.

[4] Campos, G. (2003), "Implicaciones Económicas del Concepto de Empleabilidad", Aportes: Revista de la Facultad de Economía-BUAP, año VIII, núm. 23, Puebla, Benemérita Universidad Autónoma de Puebla, pp. 101-111.

[5] Collaborative for Academic, Social, and Emotional Learning (CASEL) (2010), Aprendizaje Social y Emocional, Chicago, CASEL <https://casel.org/wp-conten t/uploads/2020/10/SEL-Framework-Spanish.pdf> [Accessed: July 2019].

[6] Cotton, K. (1993), "Developing Employability Skills", School Improvement Research Series, Close-Up \#15, Education Northwest, <https://educationnorthwest.org/site
s/default/files/DevelopingEmployabilitySkills.pdf> [Accessed: June 2019].

[7] Extremera N. y Pena M. (2016), "Competencias socioemocionales y empleabilidad", ¿Cómo orientar profesionalmente a tu hijo?, Madrid, Fundación Bertelsman, pp.172-183,

$<$ http://orientaratuhijo.com/wp-content/uploads/2016/09/be rtelsmann_guia_padres_capitulo-13.pdf $>$ [Accessed: July 2019].

[8] García J. y Pérez C. (2008), "Espacio Europeo de Educación Superior, competencias profesionales y empleabilidad", Revista Iberoamericana de Educación, vol.46, núm. 9, Madrid, Organización e Estados Iberoamericanos para la Educación, la Cienca y la Cultura, pp. 1-12, < https://rieoei.org/RIE/article/view/1886> [Accessed: July 2019].

[9] Gómez, J. (2015), "Fomentar la ética en las organizaciones a todos los niveles, desde de la base de la pirámide organizativa y hacia fuera", Cerem Comunicación, Madrid, Cerem International Business School,

$<$ https://www.cerem.pe/blog/fomentar-la-etica-en-las-orga nizaciones-a-todos-los-niveles-desde-de-la-base-de-la-pira mide-organizativa-y-hacia-fuera $>$ [Accessed: August 2019].

[10] Jagers R., Rivas-Drake D. y Williams B. (2019), "Transformative Social and Emotional Learning (SEL): Toward SEL in Service of Educational Equity and Excellence", Educational Psychologist, vol.54, núm. 3, Ann Arbor, pp. 164-184, <https://casel.org/wp-content/uploads/ 2020/06/Transformative-Social-and-Emotional-Learning-S EL-Toward-SEL-in-Service-of-Educational-Equity-and-Ex cellence.pdf $>$, [Accessed: July 2019].

[11] Layer, G. (2004), "Widening participation and employability", Learning \& Employability, Series 5, Reino Unido, Learning and Teaching Support Network, pp. 1-24,

https://www.qualityresearchinternational.com/esecttools/es ectpubs/Widening\%20Participation\%20and\%20employabi lity.pdf $>$ [Accessed: July 2019].

[12] Maella, P. (2016). "Las claves de la automotivación en el trabajo", Observatorio de Recursos Humanos y RR.LL., núm. 116, Madrid, ORH Grupo editorial de conocimiento y gestión, pp. 42-47, <http://www.gref.org/nuevo/articulos/a rt_221016.pdf> [Accessed: August 2019].

[13] ManpowerGroup (2018). "Resolviendo la Escasez de Talento. Construir, Adquirir, Tomar prestado y Tender puentes", Encuesta de escasez de talento-Perú, Lima, Reputation Leaders, <http://www.manpower.com.pe/mpint ranet/publicaciones/5686-7070551448398.pdf > [Accessed: July 2019].

[14] Montuschi, L. (2004). "Etica y razonamiento moral. Dilemas morales y comportamiento ético en las organizaciones", Econstor, Serie de documentos de trabajo, núm. 219, Buenos Aires, Univesidad del Centro de Estudios Macroeconómicos de Argentia (UCEMA), pp 1-40, $<$ https://www.econstor.eu/bitstream/10419/84263/1/35420 7474.pdf $>$ [Accessed: July 2019].

[15] Pérez de los Cobos, F. (2010), "El conflicto laboral en la actualidad: Los nuevos conflictos". Lus et Praxis, vol. 16, núm.1, pp. 441-452, <https://scielo.conicyt.cl/pdf/iusetp/v1 6n1/art14.pdf $>$, [Accessed: July 2019]. 
[16] Real Academia Española (2019). "Diccionario de la lengua española", RAE, núm. 23 ed, <https://dle.rae.es/empleabili dad> [Accessed: July 2019].

[17] Social and Emotional Learning Chile (2019). Aprendizaje Socioemocional para la Convivencia Escolar, Santiago de Chile, SEL Chile, <https://selchile.com/quienes_somos/> [Accessed: July 2019].

[18] Sistema Nacional de Evaluación Acreditación y Certificación de la Calidad Educativa (2017), SINEACE, Lima, SINEACE, <https://www.sineace.gob.pe/> [Accessed: August 2019].

[19] Stasz, C. (1998), "Generic skills at work: implications for occupationally-oriented education", Key qualifications in work and education, Springer Science+Business Media, pp. 187-206.
[20] Universidad Continental (2006), Plan de estudios 2007 Presencial Administración. (Diseño institucional de planes de estudios), Huancayo, Universidad Continental.

[21] Universidad Continental, (2006), Plan de Estudios 2007 Presencial Ing. de Sistemas e Informática. (Diseño institucional de planes de estudios), Huancayo, Universidad Continental.

[22] Villanueva, L. (2015), "La toma de decisiones en la organización y el gran valor del profesional de la información en su desarrollo", Infotecarios, Santiago de Chile,

Infotecarios, $<$ https://www.infotecarios.com/la-toma-de-de cisiones-en-la-organizacion-y-el-gran-valor-del-profesiona 1-de-la-informacion-en-su-desarrollo/\#.X4-sFNBKiM8> [Accessed: September 2019]. 